\title{
Comparison of USG Guided Pigtail Catheterisation Vs Open Drainage in the Management of Liver Abscess
}

\author{
Avanish Kumar Saxena ${ }^{1 *}$, Juhi Singhal ${ }^{1}$, Amrita Gupta ${ }^{2}$, Abhishek Kumar Rai ${ }^{3}$ \\ ${ }^{1}$ Associate Professor, ${ }^{3}$ PG Student, Department of Surgery, \\ S. N. Medical College, Agra, Uttar Pradesh, India. \\ ${ }^{2}$ Lecturer, Department of Anaesthesia, S. N. Medical College, Agra, Uttar Pradesh, India.
}

\section{Article History}

Received: 22 Nov 2015

Revised: 04 Dec 2015

Accepted: 26 Dec 2015

*Correspondence to:

Dr. Avanish K Saxena, Associate Professor, Department of Surgery, S. N. Medical College, Agra, Uttar Pradesh, India.

\section{ABSTRACT}

Introduction: Liver abscess is a fatal disease. There is a shift in the treatment modality of choice from open surgery to minimal invasive procedure like percutaneous drainage.

Aim: Our aim is to compare the USG guided pigtail catheterisation vs open drainage in terms efficacy, success rate, clinical improvement, time needed for total resolution of abscess and duration of hospital stay for the patients

Results: There is male dominance in both the groups. Raised ESR and Leucocytosis is seen in both the groups. Clinical improvement as seen by relief from fever and leucocytosis is comparable in both the groups. Efficacy is $100 \%$ in SD group while it is $96.6 \%$ in PD group. Time needed for total reduction of cavity size and hospital stay was significantly less in PD group as compared to SD group $(\mathrm{p}<0.03)$. Morbidity is also less in PD group $(30 \%)$ as compared to SD group $(36.6 \%)$.

Conclusion: Hence we conclude that USG guided percutaneous drainage is better alternative to surgery for liver abscess as it is effective, non-invasive and has less morbidity.

KEYWORDS: USG Guided Pigtail Catheterisation, Liver Abscess, Minimal Invasive Procedure.

\section{INTRODUCTION}

Liver abscess are most commonly due to pyogenic, amoebic or mixed infection. Less commonly these may be fungal in origin. The prevalence of amebic infection is $5-10 \%$ in endemic areas and sometimes as high as $55 \% .^{2}$ In India amoebic abscess is endemic. It is found most commonly in men between $20-40$ yrs. of age but can occur at any age. The primary mode of treatment is medical ${ }^{3,4}$ but $15 \%$ of these may be refractory to medical treatment. In these cases percutaneous drainage remains the mainstay of treatment. ${ }^{5}$ Liver abscess larger than 5 $\mathrm{cm}$ in size requires prompt drainage for resolving sepsis. ${ }^{6}$ Large abscess if multiloculated or if it contain thick viscid pus could result in failure of percutaneous drainage while surgical drainage allow for breakage of multiloculi and drainage of viscid pus. Our aim of study is to study and compare USG guided pigtail catheterization v/s open drainage in the management of liver abscess in terms of efficacy, success rate, clinical improvement, time needed for total resolution of abscess and duration of hospital stay for the patients.

\section{MATERIALS AND METHODS}

After obtaining approval from institutional ethical committee this prospective study was conducted in 60 patients with liver abscess who admitted in surgery department of S.N. Medical College, Agra.

Diagnosis of liver abscess was made on the basis of clinical history, serologic testing (IgM Elisa) and examination followed by USG. Routine investigations were done.

The patients included in the study were having non complicated abscesses with no features of rupture, no feature of impending rupture (liver tissue rim $>1 \mathrm{~cm}$ ), no compression effect and abscess size $>5 \mathrm{~cm}$ diameter. The patients with multiple abscess cavities, ruptured/impending rupture, symptoms and signs of peritonitis, abscess $<5 \mathrm{~cm}$ diameter were excluded from the study. After selection of patients, they were randomly allocated into two groups.

Group PD: Percutaneous Catheter Drainage (PCD) (Pig Tail Catheterisation).

Group SD: Open surgical drainage. 
Randomization was done using computer software according to standardized previously reported protocol. Informed consent was taken from all patients undergoing the above therapy. Antimicrobial therapy in the form of metronidazole (i.e. $40 \mathrm{mg} / \mathrm{kg}$ body weight / day) in three divided doses and third generation cephalosporin (i.e. $40-50 \mathrm{mg} / \mathrm{kg}$ body weight / day) in two divided doses was given to all patients for 10 days. For percutaneous catheter drainage, appropriate sized catheters (8-12 fr pigtail) were introduced into the abscess cavity using the Seldinger technique. The catheter was connected to a completely closed collecting system and routine catheter care was instituted. A daily estimate of the amount, color and consistency of drainage fluid was recorded .Irrigation of the catheter with sterile saline water 51 was done daily to avoid catheter blockage. Catheter was removed when catheter output dropped to $<10 \mathrm{ml} / 24 \mathrm{hrs}$ for 2 consecutive days, the patient showed clinical improvement (i.e. defervescence and relief from local symptom and normalization of elevated leucocyte count) and follow up sonography showed negligible residual cavity. Open surgical drainage was done through a transperitoneal approach. This allowed for abscess drainage and an abdominal exploration to identify previously undetected abscesses and if possible the location of an etiologic source Drainage was carried out by complete removal of all pus. Intra-abscess loculations were broken down by gentle blunt dissection. Following drainage, the abscess cavity was flushed with saline for clearance of residual pus and necrotic debris. Large-bore soft tube drains (28 Fr) were placed within the abscess cavity proper. Drainage tubes were removed only after drainage is minimal ( $<10 \mathrm{ml}$ for 2 consecutive days). All patients were followed up to assess the time needed for clinical improvement, length of hospital stay and development of any complications. Patients were followed as inpatients during therapy for 10 days and reexamined weekly for a month after discharge. Body temperature, pain, and tenderness of the right upper abdomen were followed daily from day 1 to 10 . WBC and haemoglobin were measured on day 1, 4, 7, 10 and after 28 days of discharge; ESR 52 on day 1, 10 and after 28 days of discharge. Periodic sonography was done every 4th day to assess the cavity size until the patients were hospitalized. After discharge all patients were followed up with periodic clinical and sonographic examinations to assess for any reoccurrence of disease and to monitor the size of the abscess cavity. The patient will be evaluated ultrasonographically after 15 days and then monthly to look for residual abscess and time taken for complete resolution of liver abscess.

\section{Statistical Analysis}

Independent $t$ test was used for comparing numerical variables among two groups. The categorical variables were analyzed by Pearson Chi Square test or Fischer exact test. $\mathrm{P}<0.05$ was considered clinically significant.

Table 1: Comparative Clinical parameters in two groups

\begin{tabular}{lcc}
\hline Parameter & Group -A & Group - B \\
\hline Age (Years) Range & $18-60$ & $21-60$ \\
Mean $\mathbf{n}$ SD & $36 \pm 11.5$ & $35.9 \pm 10.1$ \\
Sex M:F Ratio & 26 Male & 23 Male \\
& 4 Female & 7 Female \\
Fever $>$ 37.2 & $6.5: 1$ & $3.3: 1$ \\
Pain in Right upper Abdomen & $30(100 \%)$ & $29(96.7 \%)$ \\
Tenderness in right upper abdomen & $30(100 \%)$ & $30(100 \%)$ \\
Jaundice & $24(80 \%)$ & $28(93.3 \%)$ \\
Diarrhoea & $3(10 \%)$ & $3(10 \%)$ \\
Nausea/Vomiting & $6(20 \%)$ & $8(26.7 \%)$ \\
Anorexia & $8(26.7 \%)$ & $6(20 \%)$ \\
Weight loss & $22(73.3 \%)$ & $18(60 \%)$ \\
Hepatomegaly & $7(23.3 \%)$ & $6(20 \%)$ \\
\hline
\end{tabular}

Table 2: Comparative laboratory parameters on admission

\begin{tabular}{lcc}
\hline Parameters & Group A $(\mathbf{n}=\mathbf{3 0})$ & Group B $(\mathbf{n}=\mathbf{3 0})$ \\
\hline Hemoglobin (g/dl) & $11.04 \pm 0.58$ & $11.18 \pm 0.61$ \\
Raised ESR (mm after 1 hour) & 44.5 & 43.5 \\
Leucocytosis & $11225 \pm 1713$ & $11243 \pm 1877$ \\
Abscess volume (ml) range Mean \pm SD & $140-1000$ & $142-1200$ \\
& $363 \pm 225$ & $365 \pm 249$ \\
\hline
\end{tabular}




\section{RESULTS}

Mean age in group PD was $36 y$ r while in group SD it was 35.9yr.There is male predominance in both the groups. A commonest symptom in both the groups was abdominal pain. Next common symptom was fever which was present in all patients of group PD and 29 patients in group SD. In both the groups (table 1) Haemoglobin and Liver function test was in normal range. Leucocytosis was present in $85 \%$ of cases and raised ESR in $90 \%$ of cases in both the groups. Volume of abscess ranged from 114 to $1200 \mathrm{ml}$ 9(Table2). In group PD, success rate was $96.67 \%$ while in group SD success rate was $100 \%$. Total clinical improvement was seen in 4-8 days and 4-7days in Group PD and Group SD respectively. Time needed for total reduction was 517 weeks in Group PD and 7-24 weeks in group SD. Hospital stay was 5-18 days and 6-21 days in group PD and SD respectively (Table 3). Morbidity is $30 \%$ in group PD and $36.6 \%$ in group SD. (Table 4)

Table 3: Outcome in different groups

\begin{tabular}{|c|c|c|c|c|c|}
\hline \multirow[t]{3}{*}{ Parameters } & \multicolumn{4}{|c|}{ Treatment groups } & \multirow{3}{*}{$\begin{array}{l}\text { P Value (by } \\
\text { chi square } \\
\text { test) }\end{array}$} \\
\hline & \multicolumn{2}{|c|}{$\begin{array}{c}\text { Group-A } \\
\text { Catheter } \\
\text { drainage }[n=30]\end{array}$} & \multicolumn{2}{|c|}{$\begin{array}{c}\text { Group-B } \\
\text { Open surgical } \\
\text { drainage }[\mathrm{n}=\mathbf{3 0}]\end{array}$} & \\
\hline & $\begin{array}{c}\text { No. of } \\
\text { patients }\end{array}$ & Value & $\begin{array}{c}\text { No. of } \\
\text { patients }\end{array}$ & Value & \\
\hline Efficacy & 29 & $97.0 \%$ & 30 & $100.0 \%$ & 0.0007 \\
\hline Success rate & 29 & $96.67 \%$ & 30 & $100.0 \%$ & 0.0008 \\
\hline Clinical improvement & 29 & $\begin{array}{c}4-8 \\
5.6 \pm 1.35 \text { days }\end{array}$ & 30 & $\begin{array}{c}4-7 \\
5.63 \pm 1.63 \text { days }\end{array}$ & 0.09 \\
\hline $\begin{array}{l}\text { Time needed for Total } \\
\text { reduction }\end{array}$ & 29 & $\begin{array}{c}5-17 \\
9.88 \pm 5.5 \text { weeks }\end{array}$ & 30 & $\begin{array}{c}7-24 \\
10.5 \pm 3.66 \text { weeks }\end{array}$ & 0.0366 \\
\hline Hospital stay & 29 & $\begin{array}{c}5-18 \\
9.94 \pm 4.45 \text { days }\end{array}$ & 30 & $\begin{array}{c}6-21 \\
12.3 \pm 4.57 \text { days }\end{array}$ & 0.0369 \\
\hline
\end{tabular}

Table 4: Morbidity of Patients: Specific Complications

\begin{tabular}{|c|c|c|}
\hline Specific Complications & Percutaneous Drainage(N=30) & Surgical Drainage $(\mathbf{N}=30)$ \\
\hline Bleeding & - & 3 \\
\hline Intra-abdominal Abscess & - & 1 \\
\hline Wound Infection & - & 7 \\
\hline Catheter blockage & 1 & \\
\hline Catheter Dislodgement & 3 & \\
\hline Fistula Formation & 1 & \\
\hline Peritonitis After Drainage & 4 & \\
\hline Intestinal Obstruction & - & 1 \\
\hline$\%$ of Patients with complications & 30 & 36.66 \\
\hline
\end{tabular}

\section{DISCUSSION}

The incidence of pyogenic liver abscess has remained unchanged since just before the mid $20^{\text {th }}$ century. Studies indicate male to female ratio is approximately $2: 1$ and the problems occurred most commonly in fourth to sixth decade of life $^{7}$ thesis, Liver abscess is most common extra intestinal infection in 3-9\% of patients.

Percutaneous catheter drainage treatment is one of the standard treatment for managing liver abscess. ${ }^{8,9}$ Surgical exploration is done for few indications only like ruptured abscess, multiloculated abscess with viscid pus. However catheter drainage has lower success rate than surgery which is seen in our case also. ${ }^{10}$ The attraction of percutaneous drainage is related to its minimal invasive approach and the ability to perform procedure without the need of general anaesthesia. Selected series of percutaneous drainage has success rate of more than $95 \% .^{11,12}$

In our case male predominance is seen as in various other S tudies. ${ }^{13,14}$ Leucocytosis with raised ESR is seen in many patients. ${ }^{15-17}$

Clinical improvement was as seen by resolution of fever, local symptoms and leucocytosis was similar in both the groups. $^{18,19}$

Time needed for total reduction of cavity size and hospital stay was significantly less in PD group as compared to surgical group. Morbidity was also less in 
catheter drainage group as compared to surgical group as catheter drainage is less invasive procedure. There is rapid shift towards the low risk, less invasive, cost effective procedure such as PCD as compared to surgery which results in more morbidity and hospital stay leading to increase in overall cost.

\section{CONCLUSION}

Percutaneous catheter drainage (PCD) is considered as standard treatment of choice and is safe and effective mode of liver abscess. It results in early relief of symptoms and faster resolution of abscess cavity. PCD also has low morbidity with good success rate so it can be used as first line management in liquefied moderate sized abscess but surgery can also be mode of treatment for liver abscess drainage with concurrent intraabdominal pathology, multiloculated abscess with biliary communication and failure of percutaneous drainage.

\section{REFERENCES}

1. Blazquez S, Rigotheir MC, Huerre M, et al. Initiation of inflammation and cell death during liver abscess formation by entamoeba histolytica depends on activity of galactose/N acetyl D galactosamine lactane. Ind J Parasitol. MAR2007; 37(3-4):425-33.

2. Stanley SL Jr. Amoebiasis Lancer. Mar 22 2003; 361(9362) : 1025-34.

3. Kapoor OP. Surgical Amoebiasis - treatment is often conservative. Bombay Hospital J 1990;32:128-33.

4. Saraswat VA, Agarwal DK, Baijal SS et al. Percutaneous catheter drainage of amoebic liver abscess. Clin radiol 1992;45:187-9.

5. Van Sonneberg Muellar PR Ferruci JT. Percutaneous drainage of abdominal abscess and fluid collection in 250 cases, part 1: results failures and complications. Radiology 1984;151:343-7.

6. Chung YFA et al Management of pyogenic liver abscess- percutaneous or open drainage. Singapore Medicine Journal 2007; 48(12):1158-65

7. Branum GD Tyson GS, Branum MA, Meyers WC. Hepatic Abscess changes in Etiology, diagnosis and management. Ann Surg 1990 Dec. 212(6): 655-62.

8. Gerzof SG Johnson WC, Robins AH, et al. Intrahepatic pyogenic abscess. Treatment by percutaneous drainage. Am J Surg 1985;149:487-94.

9. Rajak CL, Gupta S, Jain S, et al. Percutaneous Treatment of liver abscess. Needle aspiration Vs. Catheter drainage. Am J Roentgenol 1998; 170:1035-39. 10. Bertel CK Van Heerden JA, Sheedy PF 2nd. Treatment of pyogenic hepatic abscess: Surgical vs percutaneous drainage. Arch Surg. 1986;121:554-58.
11. Miller FJ, Ahola DT, Bretzman PA, et al. Percutaneous management of hepatic abscess: A prospective by interventional radiologists. J Vasc Interv Radiol. 1997;8: 241-7.

12. Johnson RD, Mueller PR, Ferrucci JT, et al. Percutaneous drainage of pyogenic liver abscesses. AJR Am J Roetengenol. 1985;144:463-67.

13. Alkofer B, Dufay C, Parienti JJ, Lepennec V, Dargere S, Chiche L. Are pyogenic liver abscesses still a surgical concern? A Western experience. HPB Surgery. 2012:316013.

14. Ng WC, Li WH, Cheung MT. Audit of management of pyogenic liver abscess in a tertiary referral hospital. Surgical Practice. 2008;1:7-10.

15. Rahimian J, Wilson T, Oram V, Holzman RS. Pyogenic liver abscess: recent trends in etiology and mortality. Clin Infect Dis. 2004;11:1654-9.

16. Chou FF, Sheen-Chen SM, Chen YS, Chen MC. Single and multiple pyogenic liver abscesses: clinical course, etiology, and results of treatment. World J Surg. 1997;4:384-9.

17. Singh O, Gupta S, Moses S, Jain DK. Comparative study of catheter drainage and needle aspiration in management of large liver abscesses. Indian $\mathbf{J}$ Gastroenterol. 2009;3:88-92.

18. Yu Meng Tan, Alexendar Yaw et al An appraisal of surgical and percutaneous drainage for pyogenic liver abscess larger than 5 cms Ann Surg 2005; 241(3) :48590 .

19. Ferraioli GI, et al. Percutaneous and surgical treatment of pyogenic liver abscess: observation over 21 year period in 148 patients. Dig Liver Dis. 2008;40(8):690-6.

\section{Source of Support: Nil.}

Conflict of Interest: None Declared.

Copyright: (C) the author(s) and publisher. IJMRP is an official publication of Ibn Sina Academy of Medieval Medicine \& Sciences, registered in 2001 under Indian Trusts Act, 1882.

This is an open access article distributed under the terms of the Creative Commons Attribution Non-commercial License, which permits unrestricted non-commercial use, distribution, and reproduction in any medium, provided the original work is properly cited.

Cite this article as: Avanish Kumar Saxena, Juhi Singhal, Amrita Gupta, Abhishek Kumar Rai. Comparison of USG Guided Pigtail Catheterisation Vs Open Drainage in the Management of Liver Abscess. Int J Med Res Prof. 2016, 2(2); 346-49. 